\title{
Histopathological aspects of breast cancer in relation to some epidemiological risk factors
}

Esti Soetrisno*, Gunawan Tjahjadi*, Goi Sakamoto•, Joedo Prihartonot, Yoshiyuki Ohnof, Didid Tjindarbumi\#, Santoso Cornain*, Setyawati Budiningsiht, Sadao Suzukif, Muchlis Ramli\#, Idral Darwis\#, Endang Sri Roostini*, Kenji Wakail'f, Drupadi S Dillon•

\begin{abstract}
Abstrak
Penelitian epidemiologik dengan cara kasus kontrol pada 300 kasus kanker payudara di Rumah Sakit Dr. Cipto Mangunkusumo, telah dilakukan pada tahun 1989-1991. Dengan menggunakan klasifikasi yang dianjurkan oleh Japanese Breast Cancer Society, gambaran histopatologik kanker payudara menunjukkan bahwa dari tipe karsinoma duktus invasif, jenis skirus ditemukan pada 147 kasus (49\%), jenis padat tubuler pada 79 kasus (26.33\%) dan jenis pa pilotubuler pada 39 kasus (13\%). Sedang dengan menggunakan klasifikasi WHO (1981), ditemukan 265 kasus (88.33\%) invasif duktus karsinoma, karsinoma invasif lobuler pada 7 kasus (2.33\%), karsinoma moduler pada 17 kasus (5.68\%), karsinoma adenoid kistik pada 1 kasus (0.33\%), penyakit Paget pada puting 2 kasus (0.67\%) dan 4 kasus pada karsinoma noninvasif adalah karsinoma duktal insitu. Analisa terhadap faktor-faktor risiko yang bermakna pada kanker payudara wanita Indonesia menunjukkan bahwa faktor-faktor: aktivitas seksual dini, tinggal di daerah perkotaan, trauma payudara, obesitas (kegemukan), haid pertama/menarche yang terlambat, siklus haid yang tidak teratur, menopause, konsumsi makanan berlemak dan yang mengandung santan dapat meningkatkan risiko. Juga telah dianalisa hubungan antara faktor-faktor risiko yang bermakna tersebut dengan jenis histopatologik. Hasilnya menunjukkan bahwa Konsumsi makanan bersantan meningkatkan kemungkinan jenis karsinoma duktus invasif. Pengaruh tersebut berhubungan dengan ketiga subtipe histologik, yaitu papiler tubuler; solid tubuler dan skirus. Konsumsi minuman dengan santan/air kelapa dan sayuran segar menurunkan kemungkinan jenis tersebut, dengan sifat tidak bergantung kepada subtipe histologik.
\end{abstract}

\section{Abstract}

Case control epidemiological study of 300 breast cancer cases from Dr. Cipro Mangunkusumo Hospital has been performed in 1989-1991. By applying the Japanese Breast Cancer Society classification, the histopathological pattern of breast cancer showed that from the invasive ductal carcinoma type, scirrhous type was found in 147 cases (49\%), solid-tubular type in 79 cases (26.33\%) and papilotubular type in 39 cases (13\%). According to WHO classification (1981); they were diagnosed as: invasive ductal carcinoma in 265 cases (88.33\%), invasive lobular carcinoma in 7 cases (2.33\%), medullary carcinoma in 17 cases (5.68\%), adenoid cystic carcinoma in 1 case $(0.33 \%)$, pure Paget's disease of the nipple in 2 cases (0.67\%) and 4 cases (1.33\%) of the noninvasive carcinoma were ductal carcinoma in situ. Analysis of the significant riskfactors among the Indonesian female breast cancer revealed that thefollowing factors: living at urban area, young sexual activity, trauma, obesity, late menarche, irregular cycle, menopause, fatty diet and coconut milk containing food consumption increased the risk. Relationship of the risk factors to histopathological types has been stastistically analyzed. The results showed that increased possibility to have the invasive ductal carcinoma was related to consumption of coconut milk containing food. The effect was related to the three histological subtypes, namely: papillary tubular, solid tubular and scirrhous types. Coconut milk drinks and fresh vegetables showed decreasing effect, which was irrespective to subtypes.

Keywords: Breast cancer, histopathological, epidemiological, risk factors .

* Department of Anatomic Pathology, Faculty of Medicine, University of Indonesia, Jakarta 10430, Indonesia

- Department of Pathology, Cancer Institute Hospital, Tokyo 170, Japan

$\mathrm{t}$ Department of Community Medicine, Faculty of Medicine, University of Indonesia, Jakarta 10320, Indonesia

'IDepartment of Preventive Medicine, Nagoya University School of Medicine, Nagoya 466, Japan

\# Department of Surgery, Faculty of Medicine, University of Indonesia, Jakarta 10430, Indonesia

- Department of Nutrition, Faculty of Medicine, University of Indonesia, Jakarta 10430, Indonesia

\section{$\bullet$}

INTRODUCTION

Breast cancers have a large variation of histological type.1.2 And the WHO classification was generally accepted to be used as a standard criterion on histological typing of whole body tumors. According to the WHO histological typing of breast cancer, 3 there are 3 main groups of breast cancer: noninvasive carcinoma (DCIS, LCIS), invasive carcinoma (11 variants, inclusive IDC-, LC-papillary carcinoma and the others/special type carcinoma as usually mention in some modification of breast cancer classification), 
Paget's disease of the nipple. In 1986, the Japanese Breast Cancer Society suggested to observe more carefully on the most common invasive breast carcinoma: IDC. As the result of their study, there are 3 subtypes of the IDC which were easily identified by light microscopic examination, namely: Papilotubular IDC, Solidtubular IDC, and Scirrhous IDC. These 3 subtypes of IDC have 10 years survival rate of $77.4 \%, 64.9 \%$ and $61.2 \%$ respectively. 4

Age influences on some breast cancer types in relation to prognostic decision. For example: lobular carcinoma tubular carcinoma, Paget's disease, usually found on an elder age, ductal carcinoma on reproductive period in women and on an elder age in men, Junevile secretory carcinoma on childhood, mucinous carcinoma among the 5th decade, medullary carcinoma in the lower decade. In general, it was known that some breast cancer types have a specific biologic behavior: indolent, circumscribe or aggressive, diffuse/massive invasive.5-12

Some difference on histological type might be found among different races. In comparative study between Japanese and American female breast cancer, it was revealed that lobular carcinoma among Japanese females was significantly lower than that among American females. The Japanese breast cancer cases had better survival compared to the American cases. 5

Race factor was established by some epidemiological observer5-9: wh ite people-women have the highest risk of suffering breast cancer and medullary carcinoma was reported more frequently among the black.

In this paper, we present the analysis on the relationship between certain histological types of breast cancer to certain demographic characteristics and risk factors.

\section{MATERIALS AND METHODS}

Collaborative tud y on etiology and clinicopathology of breasl cancer on the first three years (1989-1990) using 300 case of brea $t$ cancer and 2 matched controls population at Dr. Cipto Mangun kusumo Hospital. Several results have been presented on One Day Symposium in International Collaborative Study on Breast Cancer at Jakarta, in 1993.

Based on Tjahjadi et al.13 and Setyawati et al.14 data, it will be studied whether histopathoJogical types of breast cancer showed any relati on to some epidemiological data. The result of case distribution by histological types was as follows: noninvasive ductal carcinoma (DCIS) 4 cases (1.33\%), invasive ductal carcinoma (IDC) 265 cases $(88.33 \%)$, consisting of 3 subtypes papilotubular IDC 39 cases (13\%), solid-tubular IDC 79 cases $(26.33 \%)$, scirrbous IDC 147 cases $(49 \%)$, mucinous carcinoma 6 cases (1.33\%), medullary carcinoma 17 cases $(5.68 \%)$, invasive lobular carcinoma (JLC) 7 cases $(2.33 \%)$, adenoid cystic carcinoma Ica e $(0.33 \%)$ and Paget's disease of the nipple 2 cases $(0.67 \%)$.

The most frequent carcinoma: IDC (88.33\%), conisted of scirrhous type $49 \%$ (the most frequent carcinoma IDC subtype). Looking at the age distribution table breast cancer in you ng people was relatively rare. Cases under 30 years old were found only in 13 cases $(4.33 \%)$.

The distribution according to tumor location showed that tumors were mostly located at the left breast 172 cases $(57.33 \%)$, followed by right breast $117(39 \%)$ and 11 cases $(3.67 \%)$ were bilateral.

The epidemiological study on the 300 cases of breast cancer revealed several significant risk factors, listed as urbaner, young first sexual contact, trauma, obesity, late menarche, irregular cycle, coconut milk food, no vegetable, and as significant at $1 \%$ menopau e and fatty diet. Among 17 histological types, 3 most frequent invasive carcinoma; papillary tubular, olid tubular and scirhhous types belonging to invasive ductal carcinoma were analyzed in relation to certain risk factors. Thus, living area, menopausal status, consumption of coconut milk containing food and drinks, and vegetables were evaluated against the relationship to invasive ductal carcinoma as compared to other types. They were further evaluated against the three histological subtypes. The proportions were compared by chi-square calculation with correction for continuity.16 Test for trend was performed using loglinear regression model with Poisson error. 15

\section{RESULTS}

Basic results of our 300 cases breast cancer study presented in the following tables.

The most common histological type was the invasive ductal carcinoma (IDC): $88.33 \%$ followed by the peciaJ types: $9.67 \%$, and the non-invasive carcinoma of ductal type (DCIS): $1.33 \%$, Paget's disease of the nipple: $0.67 \%$. 
Table 1. Histological types and case distribution of breast cancer (1989-1991)

\begin{tabular}{|c|c|c|}
\hline Histological types & Nu mber of cases & $\%$ \\
\hline \multicolumn{3}{|l|}{ 1. Noninvasive carcinoma } \\
\hline - Ductal & 4 & 1.33 \\
\hline - Lobular & 0 & 0.00 \\
\hline \multicolumn{3}{|c|}{$\begin{array}{l}\text { 2. Invasive carcinoma } \\
\text { a. Invasive ductal carcinoma }\end{array}$} \\
\hline a. I. Papilotu bular & 39 & 13.00 \\
\hline a.2. Solid-tubular & 79 & 26.33 \\
\hline a.3. Scirrhous & 147 & 49.00 \\
\hline \multicolumn{3}{|l|}{ b. Special type } \\
\hline b. 1. Mucinous & 6 & 1.33 \\
\hline b.2. Medullary & 17 & 5.68 \\
\hline b.3. Invasive lobular & 7 & 2.33 \\
\hline b.4. Adenoid cystic & & 0.33 \\
\hline \multirow[t]{2}{*}{ 3. Pagets disease } & 2 & 0.67 \\
\hline & 300 & 100.00 \\
\hline \multicolumn{3}{|l|}{ Source: Tjahjadi et al. 1993} \\
\hline \multicolumn{3}{|c|}{ Table 2. Case distribution by age at operation/biopsy } \\
\hline Age at operation/biopsy & Nu mber of cases & $\%$ \\
\hline 20 - 29 years & 13 & 4.33 \\
\hline $30-39$ years & 72 & 24.00 \\
\hline 40 - 49 years & 93 & 31.00 \\
\hline 50 - 59 years & 55 & 18.33 \\
\hline $60-69$ years & 58 & 19.33 \\
\hline 70 - 79 years & 9 & 3.00 \\
\hline Total & 300 & 100.00 \\
\hline
\end{tabular}

The peak incidence was found in the 5th decade: $31 \%$. The youngest case reported was 21 years old, and the oldest case was 75 years old. The young people group (less than 30 years old) showed much lower percentage in comparison to the older people group (more than 40 years old), they were $4.33 \%$ versus $77.66 \%$. The mucinous carcinoma which were only 4 cases $(1.33 \%)$ occurring at 30 years, 44 years, 51 years and 54 years old respectively. The lobular and medullary types were similarly distributed in the age interval over 20 to 70 years. Among our 11 bilateral breast cancer cases, only 2 cases of them were lobular type.

The possibility of any kind of relationship between the histopathological types of the 300 cases of breast cancer and significant risk factors was analyzed by cross tabulation. The invasive ductal carcinoma

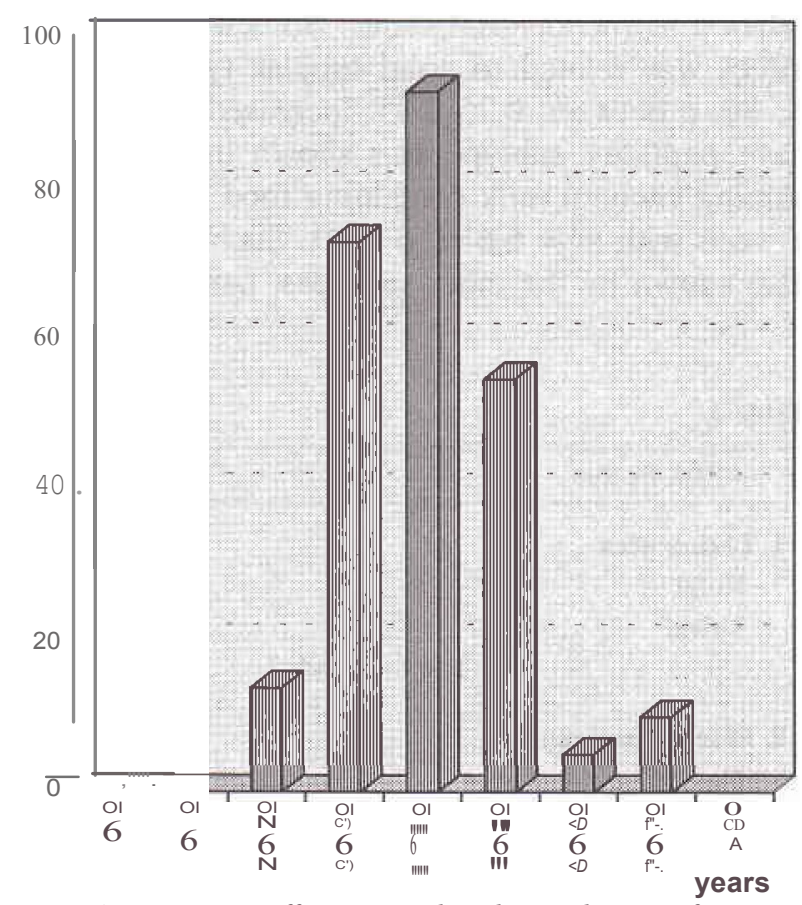

Figure 1. Histogram offrequency distribution by age of group of 300 cases of breast cancer

(IDC) type was analyzed in relation to living area, menopausal status, consumption of coconut milk containing food and drinks, fatty meat and fresh vegetables. The results are given in Table 3. There was no significant or difference in relation to IDC type or IDC type comparing between rural and urban area, with $\mathrm{x} 2=0.009$. Similarly, if they were compared according to menopausal status, with $\mathrm{x} 2=$ 0.400 .

Consumption of coconut milk food seemed to increase the possibility to have invasive ductal carcinoma compared to other types. Significant difference was shown by women who consumed cocon ut milk food less than once a week, with $\mathrm{x} 2=5.885, \mathrm{p}<0.02$. Somewhat similar pattern was shown by consumption of coconut milk drinks, except for significantly decreasing effect related to frequent consumption (34 times weekly), with $\mathrm{x} 2=4.731, \mathrm{p}<0.05$. Consuming fresh vegetables daily showed to decrease the risk significantly. Further analysis was performed by evaluating the three subtypes of IDC, namely papillary tubular type, solid tubular type and scirrhous type. The results are given in Table 4.

Accordingly, there was no significant difference among three histological subtypes in relation to living area. However, there was marginal significance in 
relation to menopausal status. Somewhat increasing effect was related to solid tubular type with $\mathrm{x} 2=$ $3.786, \mathrm{p}$ between $0.25-0.05$. Increased possibility to have papi llary subtype was shown in women consuming coconut milk containing food less than once a week with $\mathrm{x} 2=6.685, \mathrm{p}<0.01$. Such an effect was also shown by the other subtypes, namely: solid tu- bular type with $\mathrm{x} 2=4.014, \mathrm{p}<0.05$ and scirrhous type with $\mathrm{x} 2=4.857, \mathrm{p}<0.05$. The tests for trend were not significant at $\mathrm{p}$ level of 0.05 . No significant difference was seen for coconut milk drinks, fatty meat and fresh vegetables consumption relative to respective histological subtypes.

Table 3 .

\begin{tabular}{|c|c|c|c|c|c|c|}
\hline Risk factors & Invasive & Ductal Carcinoma & Others & Total & $\mathrm{x} 2$ & $\mathrm{p}$ \\
\hline \multicolumn{7}{|l|}{ 1. Living area } \\
\hline Rural & & 93 & 12 & 105 & & \\
\hline \multirow[t]{2}{*}{ Urban } & & 172 & 23 & 195 & 0.009 & \\
\hline & 0.001 & $\mathrm{p}=\mathrm{NS}$ & & & & \\
\hline \multicolumn{7}{|l|}{2 Menopausal status } \\
\hline No & & 118 & 17 & 135 & & \\
\hline \multirow[t]{2}{*}{ Yes } & & 147 & 18 & 165 & 0.400 & \\
\hline & 0.02 & $\mathrm{p}=\mathrm{NS}$ & & & & \\
\hline \multicolumn{7}{|l|}{ 3. Diet of coconut milk containing food } \\
\hline Never & & 61 & 12 & 73 & & \\
\hline Less than Ix weekly & & 92 & 6 & 98 & $5.885^{*}$ & $<0.02$ \\
\hline $1-2$ weekly & & 57 & 7 & 64 & 1.382 & \\
\hline 3-4 weekly & & 39 & 5 & 44 & 1.052 & \\
\hline \multirow[t]{2}{*}{ Daily } & & 18 & 3 & 21 & 0.331 & \\
\hline & 0.007, & $\mathrm{p}=\mathrm{NS}$ & & & & \\
\hline \multicolumn{7}{|l|}{ 4. Diet of coconut milk drink } \\
\hline Never & & 159 & 25 & 184 & & \\
\hline Less than Ix weekJy & & 80 & 6 & 86 & 3.212 & \\
\hline $1-2$ weekly & & 15 & 3 & 18 & 0.000 & \\
\hline 3-4 weekly & & J0 & 6 & II & $4.731 *$ & $<0.05$ \\
\hline \multirow[t]{2}{*}{ Daily } & & & & & 0.204 & \\
\hline & 0.08 & $\mathrm{p}=\mathrm{NS}$ & & & & \\
\hline \multicolumn{7}{|l|}{ 5. Diet of fatty meat } \\
\hline Never & & 79 & 7 & 86 & & \\
\hline Less than Ix weekly & & 80 & 15 & 95 & 1.809 & \\
\hline $1-2$ weekly & & 67 & 10 & 77 & 0.569 & \\
\hline 3-4 weekly & & 33 & 3 & 36 & 0.106 & \\
\hline Daily & & 6 & 0 & 6 & 2.320 & \\
\hline Test for trend: & 0.007 & $\mathrm{p}=\mathrm{NS}$ & & & & \\
\hline \multicolumn{7}{|l|}{ 6. Diet of fresh vegetable } \\
\hline Never & & 53 & 10 & 63 & & \\
\hline Less than Ix weekly & & 42 & 6 & 48 & 0.599 & \\
\hline $1-2$ weekly & & 46 & 10 & 56 & 0.002 & \\
\hline 3-4 Daily & & 57 & 5 & 62 & 2.619 & \\
\hline Daily & & 67 & 4 & 71 & $4.915^{*}$ & $<0.05$ \\
\hline Test for trend: & 0.48 & $\mathrm{p}=\mathrm{NS}$ & & & & \\
\hline
\end{tabular}

* the two-sided significant level was determined 
Tabel 4. Analysis of risk factors and histological type of 300 breast cancer cases

\begin{tabular}{|c|c|c|c|c|c|c|c|c|c|}
\hline & \multirow[b]{2}{*}{ Risk factors } & \multicolumn{6}{|c|}{ Histological type } & \multirow[b]{2}{*}{ Others } & \multirow[b]{2}{*}{ Total } \\
\hline & & $\begin{array}{l}\text { Papillary } \\
\text { tu bular roe }\end{array}$ & $x 2$ & $\begin{array}{l}\text { Solid tub. } \\
\text { roe }\end{array}$ & $\mathrm{x} 2$ & $\begin{array}{l}\text { Scirrhous } \\
\text { roe }\end{array}$ & $\mathrm{x} 2$ & & \\
\hline \multirow[t]{3}{*}{1.} & Living area & & & & & & & & \\
\hline & Rural & 18 & & 23 & & 52 & & 12 & 105 \\
\hline & Urban & 21 & 0.642 & 56 & 0.596 & 95 & 0.006 & 23 & 195 \\
\hline \multirow[t]{3}{*}{2.} & Menopausal status & & & & & & & & \\
\hline & No & 19 & & 27 & & 72 & & 18 & 135 \\
\hline & Yes & 20 & 0.217 & 52 & 3.786 & 75 & 0.201 & 17 & 165 \\
\hline \multirow[t]{7}{*}{3.} & $\begin{array}{l}\text { Diet of coconut milk } \\
\text { containing food }\end{array}$ & & & & & & & & \\
\hline & Never & 6 & & 21 & & 34 & & 12 & 73 \\
\hline & Less than Ix weekly & 14 & $6.685^{* *}$ & 28 & $4.014 *$ & 48 & $4.857 *$ & 6 & 98 \\
\hline & 1-2 weekly & 12 & $4.593 *$ & 17 & 0.729 & 28 & 0.819 & 7 & 64 \\
\hline & 3-4 weekly & 5 & 1.610 & 10 & 0.280 & 24 & 1.379 & 5 & 44 \\
\hline & Daily & 2 & 0.652 & 3 & 0.301 & 13 & 1.863 & 3 & 21 \\
\hline & Testfor trend: & & 0.222 & & 1.341 & & 0.612 & & \\
\hline \multirow[t]{7}{*}{4.} & Diet of coconut milk drink & & & & & & & & \\
\hline & Never & 28 & & 46 & & 85 & & 25 & 184 \\
\hline & Less than Ix weekly & 9 & 0.617 & 25 & 3.368 & 46 & 3.625 & 6 & 86 \\
\hline & 1-2 weekly & & 0.308 & 5 & 0.068 & 9 & 0.038 & 3 & 18 \\
\hline & 3-4 weekly & 1 & 2.297 & 3 & 2.136 & 6 & 2.929 & 6 & 11 \\
\hline & Daily & 0 & 0.001 & 0 & 0.085 & & 0.004 & & \\
\hline & Testfor trend: & & 1.813 & & 0.091 & & 0.708 & & \\
\hline \multirow[t]{7}{*}{5.} & Diet of fatty meat & & & & & & & & \\
\hline & Never & 11 & & 29 & & 39 & & 7 & 86 \\
\hline & Less than Ix weekly & 11 & 0.846 & 21 & 3.207 & 48 & 0.675 & 15 & 95 \\
\hline & $1-2$ weekly & LO & 0.130 & 20 & 1.004 & 37 & 0.238 & 10 & 77 \\
\hline & 3-4 weekly & 6 & 0.469 & 8 & 0.018 & 19 & 0.290 & 3 & 36 \\
\hline & Daily & & 3.421 & & 3.182 & 4 & 2.536 & 0 & 6 \\
\hline & Testfor trend: & & 0.273 & & 1.437 & & 0.416 & & \\
\hline \multirow[t]{7}{*}{6.} & Diet of fresh vegetable & & & & & & & & \\
\hline & Never & 9 & & 18 & & 39 & & 10 & 63 \\
\hline & Less than $1 x$ weekly & 5 & 0.077 & 14 & 0.525 & 48 & 2.475 & 6 & 48 \\
\hline & 1-2 weekly & 9 & 0.105 & 13 & 0.077 & 37 & 0.021 & 10 & 56 \\
\hline & 3-4 weekly & 8 & 1.321 & 15 & 1.222 & 34 & 1.502 & 5 & 62 \\
\hline & Daily & 8 & 2.022 & 19 & 3.148 & 40 & 3.291 & 4 & 71 \\
\hline & Testfor trend: & & 0.101 & & 0.142 & & 2.383 & & \\
\hline
\end{tabular}

* Significant difference at $p<0.05 ; \quad * *$ Significant difference at $p<0.01$

\section{DISCUSSION}

The age distribution of the Indonesian female breast cancer showed that a significant increase of the proportion of cases has started at the third decade $(24 \%)$ and peaked at the fourth decade $(31 \%)$. The data suggested that the breast cancer in Indonesian females The histological typing showed that the majority was

started at younger ages compared to the American the invasive carcinoma (98\%), consisting of $88.33 \%$ and the Japanese cases.5-13 The proportion sharply declined at the seventh decade, similar to the Japanese cases but differs from the American cases, which declined at the eighth decade. 
invasive ductal carcinoma and $9.67 \%$ special type. Thus, only a few non-invasive carcinoma (1.33\%) and Paget's disease of the nipple $(0.67 \%)$. The proportion were different from the Japanese cases,5-13 with higher non-invasive cases $(7.4 \%)$, lower invasive ductal carcinoma $(80.4 \%)$, lower special types $(11.4 \%)$ and similar Paget's disease $(0.7 \%)$. The present study has analyzed the relationship between several significant risk factors and the histological types. The data showed that consumption of coconut milk containing food increased the possibility to have invasive ductal carcinoma as compared to other histological types, while coconut milk containing drinks and fresh vegetables had decreasing effect. It is of interest that the increasing effect of coconut milk containing food related to papillary tubular type and the decreasing effect of coconut milk containing drinks was related to scirrhous type. It appeared that the former effect was evident in all three histological subtypes. The decreasing effect of fresh vegetables was not preferentially related to any histological subtype. Such relationship might be value for better understanding on the role of risk factors in influencing the development of breast cancer. The relationship of histological types of gastric cancer to demographic data has been also analyzed by others. 17

Further study on bigger samples is suggested to enable the analysis on other histological types and the evaluation on important epidemiological risk factors such as ethnic difference.

\section{Acknowledgments}

The authors would like to thank to the nurses, Ms. Ros and Emi, and public health nurses, Ms. July and Ms. Erlaini for excellent epidemiological data collection. We are also indebted to EDP staffs for helping in data processing. This work was supported by the Ministry of Education, Science, Sports and Culture of Japanese Government, Grants No. 01042007,04042013 and 06042006; and was partially supported by the Indonesian Cancer Foundation. This collaborative study was a part of Special Cancer Research project in Monbusho International Scientific Research Program, with the approval of the Dean, Faculty of Medicine University of Indonesia, No. 4383/PT02. H4.FK/E/88.

\section{REFERENCES}

1. Mc.Divitt RW, Steward FW, Berg JW. Tumors of the Breast: Atlas of Tumor Pathology. $2^{11} \mathrm{~d}$ series. Washington: AFIP 1968.

2. Page DL, Anderson TJ. Diagnostic Histopathology of the Breast. Edi nburg: Churchill Livingstones 1987.

3. International Histological Classification of Tumors: Histological typing of Breast Tumors. WHO 1981.

4. Japanese Breast Cancer Society. The General Rules for clinical and pathological recording of breast cancer. Jpn J Surg 1989; 19: 612-32.

5. Sakamoto G, Sugano H, Hartmann WH. Comparative pathological study of breast carcinoma among American and Japanese women. In: McGuire WL, editor. Breast Cancer. Nashville: Plenu m Publishing Corp., 1991; 4: 211-31.

6. Berg JW. Clinical Implications of Risk Factors for Breast Cancer. Cancer 1984; 1: 589-91 (supplement)

7. Gump FE. Premalignant Diseases of the Breast: Surgical Clinical North America 1984; 64: I051-59.

8. Ohno Y. Metodology and evaluation of dietary factors in Japan. In: Mettline CJ, Aoki K, editors. Recent Progress in Research on Nutrition and Cancer, pl 1-20. Wiley-Liss 1990.

9. Claus EB, Risch N, Thomson WD, Carter D. Relation between Breast Histopathology and Family History of Breast Cancer. Cancer 1993; 71: 147-53.

10. Hurliman J, Gebhard S, Gomez F. Estrogen receptor, progesteron receptor, pS2, ERD 5, HSP27 and cathepsin D in invasive ductal breast carcinoma. Histopathology 1993; 23: $239-48$.

11. Azzopardi JG, Ahmed A, Millis RR. Problem in Breast Pathology W.B.Saunders 1979.

12. Page DL. Prognosis and Breast Cancer. Recognition of lethal and favorable prognostic types. Am J Pathol 1991; 15:334-49.

13. Tjahjadi G, Sakamoto G, Tjindarbu mi D, Watanabe S, Prihartono J, Ohno Y, et al. Pathological aspects of breast cancer in Indonesian females, Emphasizing on the modified WHO classification. Med J Indones 1995; 4: 156-62.

14. Budiningsih S, Ohno Y, Prihartono J, Ramli M, Wakai K, Cornain S, et al. Epidemiological analysis of risk factors for breast cancer in Indonesian females. Med J Indones 1995; 4: 163-8.

15. Rimm AA, Hartz AJ, Kalbfleisch JH, Anderson AJ, Hoffman RG. Basic Biostatistic in Medici ne and Epidemiology. Appleton Century Crofts, New York, 1980.

16. Clayton D, Hills M. Statistical Model in Epidemiology. Oxford University Press, Oxford, 1993.

17. N, Triaspolitica. "Kanker Payudara: Informasi, Penyebab, Gejala, Stadium Dan Pengobatan." Mau Nanya Dong Dok. N.p, 28 June 2017. Web. 30 June 2017. $<$ https://nanyadongdok.blogspot.com/2017/06/kanker-payudarainformasi-penyebab.html>. 